\title{
Use of the Instream Flow Incremental Methodology: Introduction to the Special Issue
}

\author{
Berton Lee Lamb ${ }^{(1)}$, Catherine Sabaton ${ }^{(2)}$, and Yves Souchon ${ }^{(3)}$ \\ Corresponding author: Lee Lamb, lee_lamb@usgs.gov
}

Key words. - IFIM, instream flow assessment, research needs, technical history

In 1991, Harvey Doerksen was able to write a memoir discussing 20 years of instream flow work (Doerksen 1991). He recalled coming into the field in about 1973, but points out that there were many dedicated professionals working on the front line of what has become known as the environmental flow issue since at least the 1940's. One of the earliest controversies in this new field was about what to call it. Some of the candidate titles included "Stream Resource Maintenance Flow," "Base Flow," and "Minimum Flow." Although some of these terms were already in wide use by the early 1970's, the term "instream flow" was not even listed in the 1973, 1974, or 1975 editions of the Water Resources Research Catalog of keywords (Doerksen 1991: 100). When most of the authors represented in this special issue began their professional careers, the field of instream flow was still seeking a core identity and a set of organizing principles.

One of the people who had begun to describe instream flow as a kind of dynamic pattern that should mimic the natural regime was Don Tennant (1976). He recommended flow levels for seasonal periods and relative habitat quality (e.g., optimum, good, and poor) based on percentages of the mean annual flow. Tennant's approach had an international influence. For example, French legislation - the 1984 water law - selected one of the Tennant target minimum flows as a legal standard to be respected downstream by water abstraction equipment. By 1975, there was enough methodology development and differences in approach to convene conferences, which resulted in well-known publications (Stalnaker and Arnette 1976; Osborn and Allman 1976). Doerksen (1991: 101) believed it was these meetings that

(1) U.S.G.S. - 2150 Centre Ave., Building C - Fort Collins, CO 80526-8118, USA.

(2) Electricité de France/ R\&D/LNHE - 6 quai Watier - 78400 Chatou France.

(3) Cemagref, Quantitative hydroecology Laboratory, 3 bis Quai Chauveau, CP 220, 69336 F-Lyon, France. 
"...set the stage for the development of the science of instream flow." At the meeting, participants repeatedly expressed a need for an "incremental" method. By this was meant a method that would allow scientists to answer this question: For every incremental change in flow, what is the corresponding effect on fish populations? At first, this question was conceived rather simply as a reduction in the minimum flow. For example, if we reduce the lowest flow that a river experiences in a given year by $10 \%$, how much habitat change will occur and how will that change affect fish numbers? But as people worked on this problem the need for a much more dynamic incrementalism became apparent: not an annual minimum, but a monthly minimum; not a monthly but a daily or hourly timestep; not a change from some minimum value but any change in flow. What had been envisioned as a relatively simple question grew into a complex and dynamic problem that required answers from a collaboration of hydrologists and biologists.

Compounding the problem for hydrologists and biologists was the need for any resulting method to address the concerns of traditional water users, such as project developers and water managers. Doerksen (1991) believes the breakthrough came with the idea that there could be a curvilinear relationship between a physical habitat variable (such as water velocity) and a species' preference for some value of that variable. Computer models using similar physi- cal variables to predict flood effects had already been designed and biologists had begun to develop criteria for the preference of spawning salmonids for water depth and velocity (e.g., Wesche 1974; White 1975; Reiser and Bjornn 1979, Delacoste et al., 1995). Those early studies resulted in a collection of habitat suitability indices (e.g., Bovee 1978) that continues to grow to now include suitability curves for many species of fish, invertebrates, riparian plants (Stromberg et al. 1991), and even recreation activities (Just 1990). In addition to species habitat suitability curves, modeling approaches now include pre-defined habitat boxes to address known hydraulic and habitat parameters used by target species such as amphibians (Waddle 2001).

Doerksen (1991) believes that these developments - and many others - converged in the U.S. Fish and Wildlife Service, which established the Cooperative Instream Flow Service Group (later known as the Instream Flow Group) in 1975. The Instream Flow Group developed the Instream Flow Incremental Methodology (IFIM). As described by the Instream Flow Group, the IFIM faced three major challenges (Doerksen 1991: 103): First, it needed scientific credibility. Second, it was based on models that required large, non-portable mainframe computers and knowledge of hydrology and hydraulics. Third, the IFIM required extensive and expensive field data. The history of how those hurdles were overcome has yet to be written. What 
has become clear is that the IFIM is now a widely used technique with applications around the globe.

Equally clear is that the basic questions the IFIM was intended to answer and the questions raised by use of the method continue to puzzle scientists. For many years, it was almost impossible to find an article about instream flow assessment that did not cite Instream Flow Information Paper No. 12 (Bovee 1982). Those who applied the IFIM relied on that information paper as the essential guide. But the questions continued to be bothersome. As the IFIM was more frequently used, it became clear that the method was not suitable for all situations (Lamb 1993; Stalnaker et al. 1995). Despite these shortcomings the IFIM has been applied on a worldwide scale (Espinoza and Pardo, 2000; Manciola and Mearelli, 2000; Tharme, 2003). The intent of the IFIM has been toward a holistic approach to river flow management involving intra- and inter-annual flow regimes and not minimum flows (Armour and Taylor 1991: Stalnaker 1979). However, the focus of use and investigation has been on the component of the IFIM known as PHABSIM and especially the habitat-flow relationship (Souchon et al., 1989; Ginot et al. 1998; Wu and Wang, 2002; Sabaton, 2002).

Although other sophisticated tools- such as 2-dimensional models and GIS-based spatial analysis - have become available, PHABSIM has remained the most commonly used approach because it is well founded in science, with assumptions well connected to the ecology of target species. But there is little body of evidence in the peer reviewed literature that tests the assumptions of the model. The expected results in terms of validating fish population levels are still challenging, in part because longterm data and monitoring before and after flow modification are not so common (Armour and Taylor 1991; Railsback et al. 1993, Railsback and Harvey, 2001). Models of the population dynamic, including habitat strengths or thresholds are promising and more and more in use (Cheslak and Jacobson, 1990; Williamson et al., 1993; Gouraud et al., 1999; Capra et al., 2004). Recent research has also emphasized how other more systemic physical variables are important and can be modeled (Sabaton et al., 2004, Gouraud et al., 2004). The International IFIM Users' Workshop was the result of the need for IFIM practitioners to visit about all these new developments. The Workshop was held in Fort Collins, Colorado USA under the co-sponsorship of the U.S. Geological Survey and Colorado State University and included 43 papers and presentations. The papers in this Special Issue were selected from those presented at the workshop because they are important for describing where we stand today.

In the first paper, Souchon and Capra discuss the current state of habitat modeling. Although referring to the IFIM as a "worldwide standard", they address the questions that remain unanswered and suggest a sim- 
plified alternative for PHABSIM (named Estimhab) that may open the way for habitat measurements in a greater number of locations.

Thomas Payne, Steven Eggers and Douglas Parkinson give recommendations concerning the number of transects to be measured to allow a robust estimation of the relationship between the PHABSIM habitat index and discharge.

Shunroku Nakamura, Akihiko Yabuki and Noriyuki Koizumi report on use of the full IFIM in the Toyogawa River, Japan and show that the results give a fairly good indication of the availability of habitat resulting from the modeled flow regime.

Using the examples of two rivers in the United States, Robert Milhous studied the joint use of physical habitat models and time series analysis. $\mathrm{He}$ offers observations about how these two analyses can be combined. In their paper, Dudley Reiser, David Chapin, Paul DeVries and Michael Ramey offer reflections about the applicability of different types of methods for spring-fed versus run-off dominated streams. They present suggestions for selecting or developing methods appropriate to these conditions.

Knut Alfredsen, Peter Borsanyi, Atle Harby, Hans-Petter Fjelstad and Sten-Enok Wersland present a new "river editing system" that integrates different tools (hydraulic modeling, habitat modeling, river editing, visualization) for analysis and design of river rehabilitation projects and artificial habitat construction.

As a first step to population modelling of juvenile Atlantic salmon, Peter Borsanyi, Knut Alfredsen, Atle Harby, Ola Ugedal and Christine. Kraxner present a physical approach for mesohabitat assessment. Their approach is a scaling tool for physical habitat information from micro-scale to macro-scale.

Martinez-Capel, Garcia de Jalon, and Rodilla-Alma studied habitat criteria for focal velocities (i.e., nose velocities) and focal heights. They present estimations of those focal parameters and compare the results - in term of Weighted Usable Area - obtained using habitat criteria for those focal parameters to the results obtained using usual average parameters.

Tetsuro Tsujimoto and Takashi Tashiro combine a habitat suitability evaluation with a population dynamic model for attached algae. They present an application on the Yahagi River, Japan.

Mark Tompkins and Edwin Herricks used a 30-year-flow record to apply the PHABSIM to two adjacent but different reaches - in terms of habitat - of a river in Illinois. They compared the potential habitat provided during those 30 years for six species of fish in the two reaches to the number of fish of each species actually sampled in these reaches.

John Bartholow's paper evaluates the utility of the SALMOD model in the Sacramento River of California. The 
model helped estimate production potential for species of Pacific Ocean salmon.

Using a population dynamic model on trout populations of 3 French rivers, Veronique Gouraud, Catherine Sabaton and Hervé Capra show the fundamental role of temporal variability of environnemental parameters in structuring these populations.

Because the IFIM is widely used in France, Catherine Sabaton, Yves. Souchon, J.M. Lascaux and their colleagues conducted a 4-year study to validate the approach in biological terms: will an increase in WUA lead to in increase in fish biomass? They report the status of their findings as applied to Brown Trout.

\section{REFERENCES}

Armour, C.A. and J.G. Taylor. 1991. Evaluation of the Instream Flow Incremental Methodology by U.S. Fish and Wildlife Service Field Users. Fisheries 16(5): 36-43.

Bovee, K. 1978. Probability of Use Criteria for the Family Salmonidae. Instream Flow Information Paper No. 4. Fort Collins, CO: U.S. Fish and Wildlife Service (FWS/OBS/78/07).

Bovee, K. 1982. A Guide to Stream Habitat Analysis Using the Instream Flow Incremental Methodology. Instream Flow Information Paper No. 12. Fort Collins, CO: U.S. Fish and Wildlife Service (FWS/OBS/82/26).

Capra H., C. Sabaton, V. Gouraud, Y. Souchon, and P. Lim (in press). A Population Dynamics model and habitat simulation as a tool to predict brown trout demography in natural and by- passed stream reaches. River Research and Applications.

Cheslak, E.F. and A.S. Jacobson. 1990. Integrating the Instream Flow Incremental Methodology with a population response model. Rivers 1(4): 264-288.

Delacoste, M., P. Baran, Lascaux, J. M., Segura, G., Belaud, A. 1995. Ability of instream flow incremental methodology to predict brown trout spawning habitat. Bulletin Français de la Pêche et de la Pisciculture (337-9): 345-353.

Doerksen, H. 1991. Two Decades of Instream Flow: A Memoir. Rivers. 2(2): 99-104.

Espinoza, Carlos and Monica Pardo, 2000. A Multidisciplinary Approach for Allocation of Water Rights in Chilean Rivers Present and Future (abstract). Page 283 in Ugo Maione, Beatrice Majone Lehto, and Rossella Monti (Editors). New Trends in Water and Environmental Engineering for Safety and Life: Eco-compatible Solution for Aquatic Environments. Rotterdam: A.A. Balkema.

Gouraud, V. C. Sabaton, and H. Capra, 2004. Role of habitat variability in trout population dynamics: Application of a dynamic population model to three French rivers. This issue.

Ginot V., Y. Souchon, H. Capra, P. Breil, and S. Valentin 1998. Logiciel EVHA 2.0. Evaluation de l'habitat physique des poissons en rivière. Guide méthodologique, Cemagref BEA/ LHQ et Ministère de l'Aménagement du Territoire et de l'Environnement. http://www.lyon.cemagref.fr/bea/lhq/ logiciels.shtml

Gouraud V., J.L. Baglinière, P. Baran, C. Sabaton, P. Lim and D. Ombredane 2001. Factors regulating brown trout populations in two French rivers: application of a dynamic population model. Regulated Rivers: Research and Management, 17: 557-569.

Just, R. 1990. Recreational Instream Flows in Idaho: Instream Flows - 
They're Not Just for Fish Anymore. Rivers. 1(4): 307-313.

Lamb, B., 1993. Quantifying Instream Flows: Matching Policy and Technology. Chapter 7 in Lawrence J. MacDonnell and Teresa A. Rice (Editors) Instream Flow Protection in the West (Revised Edition). Boulder, CO: Natural Resources Law Center, University of Colorado.

Manciola, P. and M. Mearelli, 2000. Contribution to the Defining of the Minimum Acceptable Flow: Tiber River Basin Authority Experience (abstract). Page 28 in Ugo Maione, Beatrice Majone Lehto, and Rossella Monti (Editors). New Trends in Water and Environmental Engineering for Safety and Life: Eco-compatible Solution for Aquatic Environments. Rotterdam: A.A. Balkema.

Osborn, J. and C. H. Allman (Editors). 1976. Proceedings of the Symposium and Specialty Conference on Instream Flow Needs. Bethesda, MD: American Fisheries Society. Volumes I and II.

Railsback, S., R. F. Blackett, and N. D. Pottinger, 1993. Evaluation of the Fisheries Impact Assessment and Monitoring Program for the Terror Lake Hydroelectric Project. Rivers. 4(4): 312-327.

Railsback, S. and B.C. Harvey, 2001. Analysis of Habitat-selection Rules Using an Individual-based Model. Ecology 83 (7): 1817-1830.

Reiser, D. and T. C. Bjornn, 1979. Habitat Requirements of Anadromous Salmonids. General Technical Report. Washington, DC: U.S. Forest Service (PNW-96).

Sabaton C. 2002. Development and use of fish habitat and population dynamics models as management tools for hydropower plants: Overview of Electricité de France experience. Enviro Flows. 2002. Proceedings of the International Conference on Environmental Flows for River Systems, in- corporating the $4^{\text {th }}$ International Ecohydraulics Symposium. Unpublished proceedings. Cape Town, South Africa (March).

Sabaton C., Y. Lascaux J.M., Vandewalle F, Baran Ph., Capra H, Gouraud V., Lauters F., Lim P., Merle G. and Paty, 2004. The "Guaranteed Flow Working Group": A French evaluation of microhabitat component of IFIM based on habitat and brown trout population monitoring. This issue.

Souchon, Y., F. Trocherie, E. Fragnoud, and C. Lacombe 1989. Les modèles numériques des microhabitats des poissons: application et nouveaux développements. Revue des Sciences de l'Eau, 2: 807-830.

Stalnaker, C. B., 1979. The use of habitat structure preferenda for establishing flow regimes necessary for maintenance of fish habitat. Pages 321-337 in Ward, J.V. and J.A. Stanford. The Ecology of Regulated Streams. Plenum Press, New York and London.

Stalnaker, C. and J. L. Arnette (Editors) 1976. Methodologies for the Determination of Stream Resource Requirements: An Assessment. Logan: Utah State University.

Stalnaker, C., B. Lamb, J. Henriksen, K. Bovee, and J.Bartholow. 1995. The Instream Flow Incremental Methodology: A Primer for IFIM. Biological Report 29. Washington, DC: National Biological Service, U.S. Department of the Interior.

Stromberg, J., D. Patten, and B. Richter, 1991. Flood Flows and Dynamics of Sonoran Riparian Forests. Rivers. 2(3): 221-235.

Tharme, R. E. (2003). A global perspective on environmental flow assessment: emerging trends in the development and application of environmental flow methodologies for rivers. River Research and Applications. 19: 397-441. 
Tennant, D. 1976. Instream Flow Regimens for Fish, Wildlife, Recreation, and Related Environmental Resources. Fisheries 1(4): 6-10.

Waddle, T. (Editor) 2001. PHABSIM for Windows: User's Manual and Exercises. Fort Collins, CO: U.S. Geological Survey.

Wesche, T. 1974. Relationship of Discharge Reductions to Available Trout Habitat for Recommending Suitable Streamflows. Laramie: University of Wyoming, Water Resources Research Institute (Water Resources Series No. 54).

White, R. J. 1975. Trout Population Responses to Streamflow Fluctuation and Habitat Management in Big a Roche-a-
Cri Creek, Wisconsin. Verh. Internat. Verein. Limno. 19: 2469-2477.

Williamson S. C., J.M. Bartholow and C.B. Stalnaker, 1993. Conceptual model for quantifying presmolt production from flow dependent physical habitat and water temperature. Regulated Rivers: Research and Management. 8(1\&2): 15-28.

Wu, Fu-Chun and Chi-Feng Wang, 2002. Effect of Flow-Related Substrate Alteration on Physical Habitat: A Case Study of the Endemic River Loach Sinogastromyzon puliensis (Cypriniformes, Homalopteridae) Downstream of Chi-Chi Diversion Weir, Chou-Shi Creek, Taiwan. River Research and Applications. 18(2): 155-170. 
